\title{
Customer Behavior of Green Advertising: Confirmatory Factor Analysis
}

\author{
Doni Purnama Alamsyah ${ }^{1, *}$, Norfaridatul Akmaliah Othman ${ }^{2}$, Rudy Aryanto ${ }^{1}$, Mulyani $^{1}$, Yogi Udjaja ${ }^{1}$ \\ ${ }^{1}$ Bina Nusantara University, Jakarta, 11480, Indonesia \\ ${ }^{2}$ Universiti Teknikal Malaysia, Melaka, 75000, Malaysia
}

A R T I C L E IN F O

Article history:

Received: 13 December, 2020

Accepted: 19 January, 2021

Online: 05 February, 2021

Keywords:

Green Advertising

Customer Behavior

Environmental Issue

\section{A B S T R A C T}

The implementation of green advertising is relatively low for credibility but has an impact on green customer behavior. Based on the phenomenon, the purpose of this study is to examine factors affecting green advertising development, which is based on experienced customers towards products and advertisements and environmental issues. This research focuses on customers to create an implementation model for green advertising among companies. The study was conducted through a survey of 215 customers in West Java (Indonesia) who experienced green advertising and bought environmental-friendly products. Data were collected through a quantitative questionnaire and processed with SmartPLS to test and evaluate Confirmatory Factor Analysis (CFA). In emphasizing the study results, a fit test of the research model and research hypotheses were also being carried out by valuing the KMO. Research findings show several dimensions involved in developing green advertising, such as experience, theme, message, claim, emotion, interaction, and impact. The dimensions of green advertising were plotted in the CFA model so that the priority scale from the implementation of green advertising measurement can be detected. Customers assume green advertising as advertising that takes environmental issues of "global warming," and this issue can adopt by companies in implementing the green marketing strategy.

\section{Introduction}

Customer behavior has led to environmental sustainability; it is assessed from the increasing level of customer awareness of companies' environmental-friendly products [1]. This phenomenon provides opportunities for companies to adopt environmental-based advertising [2]. Advertisement can influence a customer to choose environmental-friendly products. Environmental-based advertising activities which also known as green advertising, is a marketing strategy that tackle the issue of environmental sustainability and health impacts among users [3]. The implementations of green advertising become important because customers have started to care about the environment with various movements, such as "green consumerism" [4], whereby the activities put forward to customer behavior in consuming and recommending environmental-friendly products [5]. Green customer behavior becomes an essential part of the company's attention in implementing marketing strategy today [6]. The issue of "green product" has become a world issue; people's behavior is changing in every country to be more

"Corresponding Author: Doni Purnama Alamsyah, doni.syah@binus.ac.id www.astesj.com

https://dx.doi.org/10.25046/aj060192 concerned about the environment as an effort to face the issue of "global warming" [5]. The efforts made by creating environmental-friendly products and decreased the production of goods and services that use chemical materials [7]. The development of environmental issues occurs in several sustainability concepts, including the concept of green living, which is an effort to live a healthier life with the attention and the use of environmental-friendly products [8]-[10].

Green advertising is part of the green marketing strategy that companies used to create awareness of green products [11]. However, the credibility of green advertising is considered low by customer. This is because customer behavior towards advertising is influence by extensive propaganda of mass media [12]. Therefore, the study of customer behavior in assessing advertising is necessary because previous research has demonstrated that the attitudes towards advertising has provided opportunities for brand attitudes changes [7]. In Indonesia, the green advertising concept was started in 2004 and has been implemented by the government to educate the environmental issue, while companies used it for corporate image [13]. The consumer's perceived value of green 
advertising focuses on $3 \mathrm{R}$ issue (reduce, reuse, recycle), no plastic day, and earth hour. The impacts of green advertising on green lifestyle and green products is still low, even though this issue is essential for companies to achieve green advertising implementation [14]. The essence of green advertising is a campaign on environmentally friendly products which support sustainability [15]. The concept of sustainability is undoubtedly considered necessary by various parties, such as the government, companies, and society [16]. The education of advertising seems to involve environmental issues in green advertising [17]. Green advertising appears to change customer behavior who cares about the environment. Indonesian government starts to implement the sustainability concept, which was started in 2012 through a regional regulation on Green Building in Jakarta [18]. As the government concern about the environment, it has become a part of green advertising which has been carried out by the government, to serve public service advertisements about the global warming issue [19]. The regulations issued by the government certainly have an impact on marketing strategy whereby companies tackle environmental issues through the concept of green advertising [20]. The characteristics of green advertising are difference with the advertising concept in general; because companies has a goal towards the image and reputation on social responsibility [21]. Hence, companies prioritize green advertising concept, not only for educating environmental-friendly products but also strengthening the company's image and reputation.

Realizing the importance on reviewing the implementation issue of green advertising in Indonesia and its impact on customer behavior, this study focuses on factor analysis that forms green advertising performance from a customer's perspective. This study intends to put forward the green advertising concept, so that it can be references by companies to campaign environmental issues, through symbols or images that are valuable to society towards sustainability concept.

\section{Literature Review}

\subsection{Green Customer Behavior}

Green customer behavior refers to customer behavior in using healthy, environmentally friendly products, and it can protect environmental sustainability [22]. Green customer behavior has a level of concern; the higher is the extraordinary impact on loyal behavior for all the environmental issues [23] and trying to recommend to others [24]. The customer's awareness of the environment prioritizes green products and campaigns for healthy lifestyles [25]. However, green customer behavior is not easy to develop [26]; it is influence by the internal situation of customers such as knowledge and self-awareness [27], and external situation of customers such as the environment [28]. Environmental factor has an important role [29] because it has greater level of interaction with customers.

\subsection{Green Customer Behavior}

Technological developments and environmental issues provide a new perspective for companies in marketing strategies through advertising media, by adopting green advertising, both offline and online [30]. Due to stiff competition, companies have started to find more creative advertising alternatives through unexpected places, unconventional methods, or unusual communication delivery [31]. It seems clear that the company's efforts are to provide awareness through advertising media, which is easy to remember and provides value for customers and the company [32]. Green advertising is believed to be a strategy that also provides opportunities to increase company's value both from the viewpoint of the product and its image [33]. It considers that green advertising has a concept that is not much different from advertising in general. However, environmental issues provide other opportunities that can be interpreted by a customer today [7]. Media in green advertising is delivered online, like social media or the internet, and offline like newspapers or billboards [34]. The previous concept states that "green advertising are advertisements that promote products, services, ideas or organizations' ability to help or reduce environmental harm" [5]. There are two elements discussed in green advertising, namely education on products or services and a positive impact on the environment [1]. The implementation of green advertising for companies is considered successful if it can provide a company's environmental image. At the same time, customers are assessed through understanding and practicing green living [7].

Green advertising is genuinely delivered by companies or the government to increase customer awareness of the environment [20]. It is undoubtedly in line with government and companies' views, which is trying to deal with the issue of "global warming" and environmental sustainability [35]. Customer care is captured in a consistent attitude that considers good or bad towards a product in the environment to recommend it to others. It seems clear that green advertising is considered effective if it can influence customers' perceptions and customer behavior in the environment [17]. In the previous studies, it has been known that the impact of green advertising on customer behavior such as concern [5], perception [17], attitude [12] to company's image [36]. However, the essential green advertising concept is the consequence of growing customer awareness of the environment [20]. There are many green marketing strategy research indicated the impact of environmental knowledge and the awareness on customer behavior towards the environment [37]. Several media become customer's references in examining the concept of green advertising, such as television, website, media social, radio, newspaper or magazine, billboards, banner dan brochure [5]. However, each media certainly provides a different level of preference; it depends on the level of persuasion given. In the end, the concept of green advertising needs to meet three main criteria, namely explicit or implicit about the correlation between products and environment [12], promoting a green lifestyle with or without products [38], and it explains company image that cares to environment [20].

\subsection{Measurements of Green Advertising}

Green advertising's implementation contains two prominent elements; informational claims and effective claims [3]. Informational claims are related to the use of environmentally friendly products advertised, while effective claims are the experiences relate to the environment. Indeed, informational and effective claims provide a positive view of customers in assessing green products [12]. There are many criterias in assessing and evaluating green advertising; several previous studies have explained that there is no definite measure that can represent green advertising [3]. All criteria depend on the objectives of green 
advertising and customer's goals that determine the success or the failure of advertising done [2], [5], [11]. Some experts' opinions explained the measurement of green advertising. Firstly, it starts with green impact, which is the importance of advertising media that takes to environmental issues into a biophysical environment, green lifestyle, and an image of environmental responsibility [21]. Secondly is a green message, where advertising is assumed necessary to give a clear message related to ecological, environmental sustainability, or nature-friendly messages [39]. The third is a green theme, where advertising needs to provide an attractive theme to be enjoyed by customers on green products that are pleasant, convincing, believable, favorable, and goods [12].

Fourthly is green emotions, where advertising can conveye the emotional values for customers in terms of environmentprotection emotion [2], [40]. Customer emotion in advertising is related to moral emotion, social emotion, and ecological fear related to climate change [2]. The fifth is related to customer's experience; it is undoubtedly essential; it is related to the green experience. Advertising is assumed as necessary to provide an experience that is assessed from the perspective of knowledge, perceived comfort, and information obtained by customers [41]. Next is assessed from green interaction related to the level of interaction that customers will feel on advertising, such as appeal, issue proximity, and environmental consciousness [42]. Finally, the measurement based on the previous studies is assessed to green claims. This measure puts forward the recognition of environmental friendly products that can meet customers' expectations in terms of degradable, recycled, recyclable, ozone friendly [43].

\section{Research Methodology}

The research method was conducted by surveying customers who purchased environmentally friendly products through a set of questionnaires. Customer were chosen from products categories that is convenient to customers, such as food and beverages. Data were carried out through online questionnaire among customer in West Java Province. The answers had been determined through Likert Scale approach, from " 1 " for strongly disagree and "7" for strongly agree. The questionnaire was distributed within three months, from August to October 2020, with a target of 300 respondents. This research was also included in experimental research where the respondents were given a treatment, which was the knowledge related to green advertising at the beginning of the questionnaire to find out their views regarding green advertising in Indonesia.

The data from respondents were processed through the Confirmatory Factor Analysis (CFA) technique; it intended to find-out the factors that determine the creation (or development?) of green advertising proposed by the research model. Meanwhile, the analysis tools used were SmartPLS, considering the ease of analyzing CFA on data below 300 . Based on the previous theory study, several elements would be studied in determining green advertising, such as green impact, green message, green theme, green emotion, green experience, green interaction, and green claim. Each dimension was measured by an indicator as shown in Figure 1. Data analysis stages were started from data tabulation, research model fit test, and research hypothesis test. Considering that this research used the CFA approach, only a fit model test through Outer Model would be conducted. It was tested for convergent validity, composite reability, average variance extracted, and discriminant validity [44], [45]. Meanwhile, the research hypothesis test was conducted by evaluating the value of Kaiser-Mayer-Olkin Measure of Sampling Adequacy (KMO MSA), where it must be more than 0.5, and the value of Bartlett's Test of Sphericity (Sig.) was smaller than 0,05 [46]. The final objective of the analysis was to find the determinant factors to develop green advertising that provide customers' value of customers'concern for environmentally friendly products.

From previous research studies, it appeared that several measurements can be assessed from green advertising. However, all of them have one goal: to increase customer awareness of green advertising implementation. In this study, the measurements that have been tested,were green impact, green message, green theme, green emotion, green experience, green interaction, and green claim [2], [21], [39], [41], [43], [47]. The essence of some of these measurements provide the same opportunity as a determining factor in assessing green advertising; before the Confirmatory Factor Analysis (CFA) is carried out, the assumptions are conveyed in the form of research hypothesis based on the CFA model as follows.

Hypothesis 1 (H1) Green impact is a dimension that can developed green advertising.

Hypothesis 2 ( $\mathrm{H} 2)$ Green message is a dimension that can developed green advertising.

Hypothesis 3 (H3) Green theme is a dimension that can developed green advertising.

Hypothesis $4(\mathrm{H} 4)$ Green emotion is a dimension that can developed green advertising.

Hypothesis 5 (H5) Green experience is a dimension that can developed green advertising.

Hypothesis 6 (H6) Green interaction is a dimension that can developed green advertising.

Hypothesis 7 (H7) Green claim is a dimension that can developed green advertising.

\section{Result and Discussions}

Confirmatory Factor Analysis (CFA) research relates to green advertising; it starts by distributing an online questionnaire for three months (August, September, October).

Data from the questionnaire spread to 215 respondents who filled in the data correctly, then data was tabulated, and the research model was tested through SmartPLS. Data analysis begins with the research instrument test, research hypothesis test, and analysis of Confirmatory Factor Analysis test result.

\subsection{Validity and Reliability Test}

Before conducting data analysis through CFA, validity, and reliability tests were examined. Considering that analysis is carried out through CFA, the tests are conducted only using the outer model test for convergent validity, composite reliability, average variance extracted, discriminant validity, and outer weight. If all the outer model test results are adequate, it is stated to be fit, and a CFA study can be carried out. 


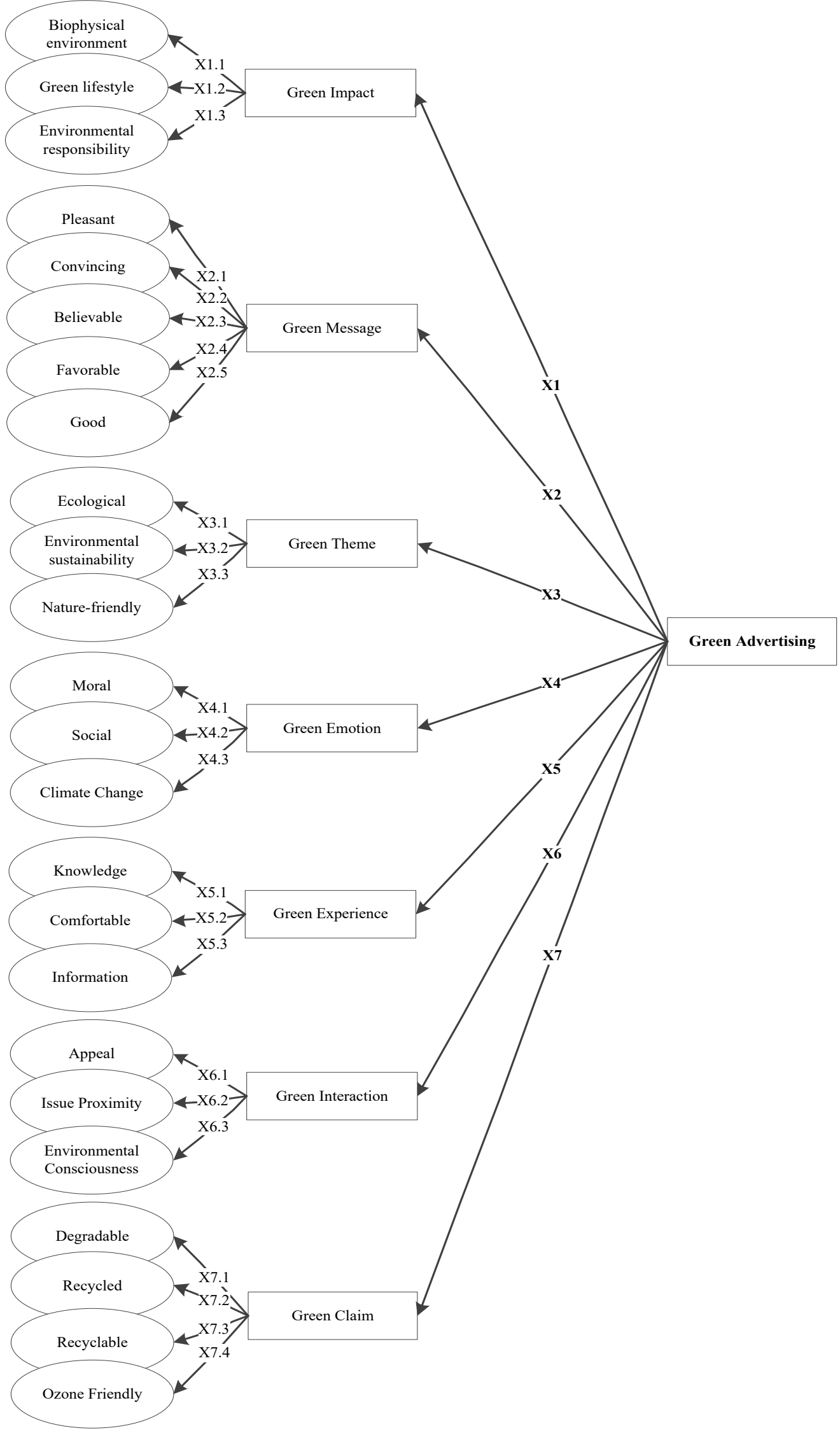

Figure 1: CFA Model 
Convergent validity test is assessed by evaluating the correlation of outer loading results, which is more than 0.50 for the correlation. Furthermore, the discriminant validity test shows whether the measured variable has acceptable reliability. Discriminant validity has known through the evaluation of the composite reliability value, which must be above 0.8 . The next test is the Average Variance Extracted (AVE) value, which is stated to be fair, and it fulfills the criteria when the value is more significant than 0.5. The next evaluation studied Cronbach's Alpha's value, which is one of the recommended discriminant validity measures to have a value above 0.7 . The final test is carried out the outer weight, which is stated to fulfill the requirements if the outer weight value is above 0.20 . The results of the first outer model test are summarized in Table 1, which indicated that from all the previous tests, composite reliability, $\mathrm{AVE}$, and discriminant validity are fulfill the requirements.

The second outer model test results which related to outer weight are summarized in Table 2, which evaluation of sample original value is above 0,20 . It is stated to be fit, or it means that it fulfills the requirements. Finally, the results of the outer model test reviewed from convergent validity, where the results are summarized in Table 3 with all of the outer loading value are accepted because the correlation value is above 0.50 . Based on all of the test results of the outer model, it can be stated that the research instrument can be accepted, and it can be analyzed further for CFA.

Tabel 1: Construct Validity and Reliability

\begin{tabular}{|l|c|c|c|c|}
\hline & $\begin{array}{c}\text { Cronbach's } \\
\text { Alpha }\end{array}$ & rho_A & $\begin{array}{c}\text { Composite } \\
\text { Reliability }\end{array}$ & $\begin{array}{c}\text { Average Variance } \\
\text { Extracted (AVE) }\end{array}$ \\
\hline Green Impact & 0,924 & 0,926 & 0,939 & 0,688 \\
\hline Green Message & 0,843 & 0,844 & 0,905 & 0,761 \\
\hline Green Theme & 0,825 & 0,827 & 0,878 & 0,590 \\
\hline Green Emotion & 0,796 & 0,796 & 0,880 & 0,710 \\
\hline Green Experience & 0,747 & 0,747 & 0,856 & 0,665 \\
\hline Green Interaction & 0,775 & 0,784 & 0,870 & 0,691 \\
\hline Green Claim & 0,773 & 0,785 & 0,868 & 0,688 \\
\hline
\end{tabular}

Tabel 2: Outer Weight Values

\begin{tabular}{|l|c|c|c|c|c|}
\hline & $\begin{array}{c}\text { Original } \\
\text { Sample (O) }\end{array}$ & $\begin{array}{c}\text { Sample } \\
\text { Mean (M) }\end{array}$ & $\begin{array}{c}\text { Standard } \\
\text { Deviation } \\
\text { (STDEV) }\end{array}$ & $\begin{array}{c}\text { T Statistics } \\
(|\mathbf{O} / \mathbf{S T D E V}|)\end{array}$ & P Values \\
\hline Biophysical Environment & 0,368 & 0,369 & 0,017 & 21,769 & 0,000 \\
\hline Green Lifestyle & 0,387 & 0,387 & 0,016 & 24,088 & 0,000 \\
\hline Environmental Responsibility & 0,391 & 0,391 & 0,016 & 24,600 & 0,000 \\
\hline Pleasant & 0,242 & 0,242 & 0,015 & 16,551 & 0,000 \\
\hline Convincing & 0,276 & 0,276 & 0,016 & 17,230 & 0,000 \\
\hline Believable & 0,270 & 0,271 & 0,014 & 18,720 & 0,000 \\
\hline Favorable & 0,254 & 0,253 & 0,017 & 15,269 & 0,000 \\
\hline Good & 0,259 & 0,259 & 0,016 & 15,899 & 0,000 \\
\hline Ecological & 0,400 & 0,401 & 0,015 & 27,331 & 0,000 \\
\hline Environmental Sustainability & 0,401 & 0,400 & 0,017 & 22,947 & 0,000 \\
\hline Nature-Friendly & 0,386 & 0,386 & 0,015 & 25,172 & 0,000 \\
\hline Moral & 0,421 & 0,420 & 0,022 & 18,967 & 0,000 \\
\hline Social & 0,393 & 0,395 & 0,015 & 26,166 & 0,000 \\
\hline Climate Change & 0,413 & 0,414 & 0,021 & 19,750 & 0,000 \\
\hline Knowledge & 0,440 & 0,440 & 0,017 & 25,158 & 0,000 \\
\hline Comfortable & 0,375 & 0,374 & 0,017 & 22,605 & 0,000 \\
\hline Information & 0,386 & 0,386 & 0,017 & 23,110 & 0,000 \\
\hline Appeal & 0,440 & 0,442 & 0,020 & 22,460 & 0,000 \\
\hline Issue Proximity & 0,345 & 0,345 & 0,022 & 15,632 & 0,000 \\
\hline Environmental Consciousness & 0,416 & 0,417 & 0,021 & 20,084 & 0,000 \\
\hline Degradable & 0,256 & 0,256 & 0,016 & 16,240 & 0,000 \\
\hline Recycled & 0,303 & 0,304 & 0,015 & 19,858 & 0,000 \\
\hline Recyclable & 0,304 & 0,304 & 0,011 & 26,755 & 0,000 \\
\hline Ozon Friendly & 0,308 & 0,308 & 0,014 & 21,757 & 0,000 \\
\hline
\end{tabular}


Tabel 3: Outer Loading Values

\begin{tabular}{|c|c|c|c|c|c|c|c|}
\hline Instruments & $\begin{array}{c}\text { Green } \\
\text { Impact }\end{array}$ & $\begin{array}{c}\text { Green } \\
\text { Message }\end{array}$ & $\begin{array}{l}\text { Green } \\
\text { Theme }\end{array}$ & $\begin{array}{c}\text { Green } \\
\text { Emotion }\end{array}$ & $\begin{array}{c}\text { Green } \\
\text { Experience }\end{array}$ & $\begin{array}{c}\text { Green } \\
\text { Interaction }\end{array}$ & $\begin{array}{l}\text { Green } \\
\text { Claim }\end{array}$ \\
\hline Biophysical Environment & 0,848 & & & & & & \\
\hline Green Lifestyle & 0,887 & & & & & & \\
\hline Environmental Responsibility & 0,882 & & & & & & \\
\hline Pleasant & & 0,748 & & & & & \\
\hline Convincing & & 0,835 & & & & & \\
\hline Believable & & 0,820 & & & & & \\
\hline Favorable & & 0,721 & & & & & \\
\hline Good & & 0,708 & & & & & \\
\hline Ecological & & & 0,848 & & & & \\
\hline Environmental Sustainability & & & 0,858 & & & & \\
\hline Nature-Friendly & & & 0,821 & & & & \\
\hline Moral & & & & 0,826 & & & \\
\hline Social & & & & 0,835 & & & \\
\hline Climate Change & & & & 0,784 & & & \\
\hline Knowledge & & & & & 0,878 & & \\
\hline Comfortable & & & & & 0,775 & & \\
\hline Information & & & & & 0,838 & & \\
\hline Appeal & & & & & & 0,862 & \\
\hline Issue Proximity & & & & & & 0,779 & \\
\hline Environmental Consciousness & & & & & & 0,845 & \\
\hline Degradable & & & & & & & 0,793 \\
\hline Recycled & & & & & & & 0,890 \\
\hline Recyclable & & & & & & & 0,860 \\
\hline Ozon Friendly & & & & & & & 0,862 \\
\hline
\end{tabular}

Table 4: Values of KMO

\begin{tabular}{|l|c|c|c|c|}
\hline \multicolumn{1}{|c|}{ Hypotheses } & KMO & Sig. & Result \\
\hline Green Impact $\leftarrow$ Green Advertising & H1 & 0,772 & 0,000 & Accepted \\
\hline Green Message $\leftarrow$ Green Advertising & H2 & 0,791 & 0,000 & Accepted \\
\hline Green Theme $\leftarrow$ Green Advertising & H3 & 0,705 & 0,000 & Accepted \\
\hline Green Emotion $\leftarrow$ Green Advertising & H4 & 0,674 & 0,000 & Accepted \\
\hline Green Experience $\leftarrow$ Green Advertising & H5 & 0,674 & 0,000 & Accepted \\
\hline Green Interaction $\leftarrow$ Green Advertising & H6 & 0,694 & 0,000 & Accepted \\
\hline Green Claim $\leftarrow$ Green Advertising & H7 & 0,826 & 0,000 & Accepted \\
\hline
\end{tabular}

\subsection{Factor Analysis of Green Advertising}

This research focuses on green advertising, which is assessed from several criteria, including green impact, green message, green theme, green emotion, green experience, green interaction, and green claim. Based on the result in Table 3, it showed that all outer-loading values are accepted; with the value above 0.70 . Outer loading values explained the level of closeness between the indicator and its dimensions because the determining indicator is better when it close to 1 . The result indicated that several factors supported the creation of dimensions on green advertising. The first dimension is green impact with a sequence of determinants, which starts from green lifestyle, environmental responsibility to the biophysical environment. The green impact is a dimension for green advertising and can motivate customers who accept advertising [48]. The first measurement, which becomes a customer's attention, is green lifestyle, where customers assume that green advertising is expected to provide a new lifestyle for healthier customers. The next dimension is green message; several supporting indicators with a sequence are convincing, believable, pleasant, favorable, and goods. Green messages can be a dimension that forms green advertising; it considers that advertising is full of messages; customers will receive advertisements recipients [39]. Customers prioritize convincing message or giving confidence because the advertisement is trustworthy and not an imaginary advertisement. Another dimension that becomes the determining factor of green advertising is green theme with indicators formed from environmental, ecological sustainability, and nature friendly. A green theme is related to a theme in online or offline advertising, considering that a theme will stimulate customers to understand the meaning of advertising [12]. In this case, a green theme that becomes the primary concern of customers is environmental sustainability issue. This is because the themes have more impact on customers' understanding in conveying the advertisement.

The next dimension is green emotion, which is formed from several indicators, such as climate change, social, and moral. 
Green emotion is considered as dimension that represent green advertising related to customers' emotional level when look at the advertisement. These emotions are positively natural-friendly, and aim to believe more in advertising behind green advertising [2]. Based on loading factor value survey, it has been revealed that the size of climate change is the most important indicator that can change customers' emotional value because green advertising relates indirectly to the issue of climate change. Green advertising lead to the assumption of customers involvement; which is stated in the green experience dimension [7]. Green experience is assessed from information, knowledge, and comfortable. Customers certainly hope that in assessing green advertising, they can improve their experience, and this experience is considered essential when it comes to the information they need. The next dimension that becomes the determining factor for green advertising is green interaction; it is formed by several indicators, such as appeal, environmental consciousness, and proximity issues. Green interaction is related to customers' interactions with the advertisements [42]; the outer loading appeal stated that it is the most influencing indicators. It means that green advertising will be able to invite interaction from customers if the advertisement is attractive. It is the reason why people said that to create content of green advertising is quite challenging because it requires special attention that relates to the environment. The last dimension is related to green claims, which consist of recycled, ozone friendly, recyclable, and degradable. It means that green claims relate to customers' recognition for the advertisements [43]. This recognition is considered as the most important recognition, because it need to ensure environmental-friendly product to be easy recycled.

A hypothesis test surely to tests the analysis results of determinants factors of green advertising; it was intended to emphasize that all the dimensions have been determined, and it can be a measurement for green advertising. The hypothesis test results are conducted by evaluating the value of KMO presented in Table 4. All "accepted" dimensions can be dimensions for green advertising. It considers that the value of KMO is above 0.5 , and the value of Bartlett's Test of Sphericity (Sig.) is smaller than 0,05 . Therefore, the result stated that the indicator factors which consist of green impact, green message, green theme, green emotion, green experience, green interaction, and green claim can develop green advertising.

\subsection{Model of CFA Green Advertising}

In the research finding of the analysis factor, there are seven dimensions of green advertising; green impact, green message, green theme, green emotion, green experience, green interaction, and green claim. However, these dimensions certainly have a different standard value informing to green advertising assessed by customers. Therefore, to determine the highest and lowest standard in green advertising, value extractions based on commonalities process [49] has been conducted, as illustrated in Figure 2.

Based on Figure 2, it is clear that the highest extraction value is green experience, and the lowest extraction value is green impact. The extraction value determines the impact's size of dimensions in determining green advertising. The findings show a composition of dimensions that can develop green advertising, which is started from experience, theme, message, claim, emotion, and interaction to impact. The dimensions need to be conducted priority scale by companies if companies decided to adjust green marketing to green advertising. These research findings explain the importance of adjusting green advertising implementation as part of marketing strategy.

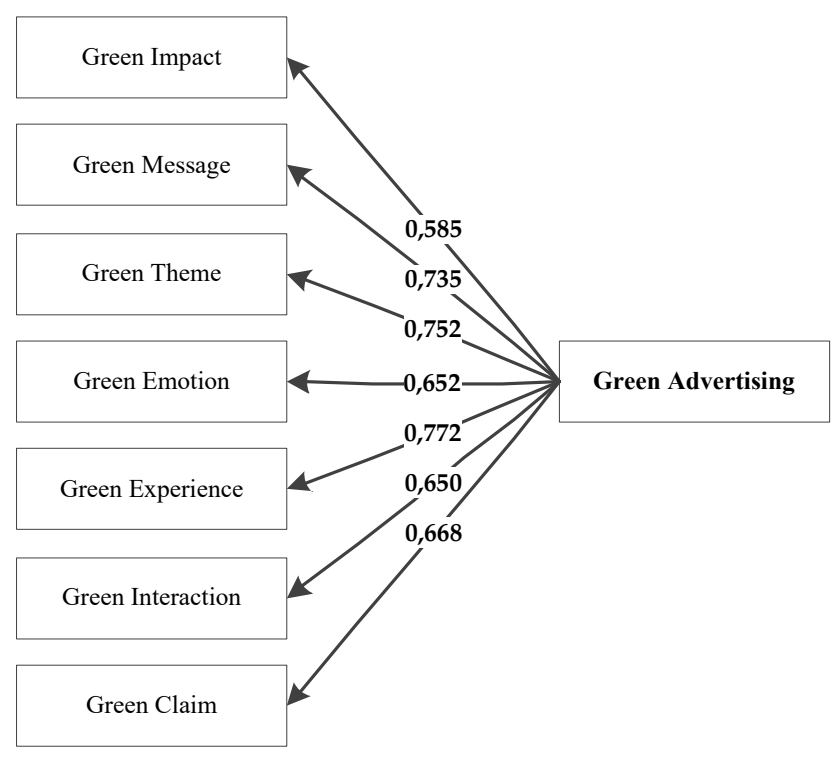

Figure 2: Model of Green Advertising

This study focuses on the behavior of customer who have purchased environmentally friendly products in Indonesia (West Java), which means that companies can utilise the model of green advertising (Figure 2 ) in promoting pure environmentally friendly products. All green advertising dimensions have meaningful content, so it would be better to develop green advertising. However, if the dimensions are to be reduced, it is advisable to start from the dimensions that have the lowest impact in developing green advertising. It means that the green advertising model's use of dimensions is adjusted to dimensional load in forming green advertising. The goal of green advertising can be achieved, namely product education that is friendly to the environment. The finding of this research can provide input for the government in advertising policies, for company in implementing green marketing and for society as customer who needs to get information related to a sustainable environment.

\subsection{Customer Perceived of Green Advertising}

Green advertising can give impacts on customer behavior by providing the assumptions and responses to environmental sustainability [1], [5]. In this case, customers of products and services offered by the company certainly need to understand the advantages and disadvantages of products they will choose, particularly for products that have a positive impact on the environment. Therefore, it is essential for company to implement green advertising. However, the implementation of green advertising needs to consider several dimensions which can develop the right customer's perception. In this study, a series of dimensions has been stated, namely: experience, theme, message, claim, emotion, and interaction. These findings are based on customers' assessment in evaluating green advertising received by them until now, and it refers to the evaluation on 
environmentally friendly products. Based on green advertising results, it can be argued that a customer's experience of green products is controls by the customer perceived value of green advertising; the theme of the conveyed advertisement; the message of the conveyed advertisement; the advertisement claim which can change customer's confidence; customer emotion is positive after seeing the advertisements; customer interaction is optimistic after seeing the advertisements; and the impact of advertising which motivates to customers to live a healthy life.

The research findings depicted in Figure 2 can be implemented by companies to educate customer on environmentally friendly products and the government in educating the importance of environmental sustainability to society. However, the model of green advertising is not suitable when used in educating conventional products or is not purely environmentally friendly because the dimensions used in this study focused on green products and the selected consumers have an environmentally friendly concern. So it is necessary to consider green advertising that companies use is not only for environmental issues, but also for the products created. This research findings explained the importance of understanding customer behavior in supporting the implementation of marketing strategies; mainly, it takes environmental issues as green advertising. There is essential information for stakeholders such as the government, companies, and society in promoting green advertising.

\section{Conclusions}

This study aims to analyze the determining factors in deciding green advertising, in which there are several measurements have been presented by the previous studies. This study provides the appropriate measurement for green advertising which can be utilized to educate customers. Seven dimensions were tested in determining green advertising, namely: experience, theme, message, claim, emotion, interaction to impact. The implementation of green advertising has impacted customers' points of view; and it considered several customers' attention. Customers' attention means experience, which consist of information, knowledge, and comfort issues. A model of green advertising through Confirmatory Factor Analysis was developed in this research. Through this model, it can provide some input to the government in evaluating the policies to deal with "global warming" issues, as well as to companies in implementing green marketing.

This research, however, has certain limitations. It applied CFA based on each dimension and does not study the impact of green advertising implementation on customer behavior, for instance customer care. Therefore, future research should emphasizes on the utilization of exploratory factor analysis (EFA) and the impact of the study on customer behavior. In addition, this research does not examine the technology used in green advertising, so it is recommended that further research to examine the technical support in green advertising, taking into consideration that that the advertising model is utilizing electronic and digital media, which are related to the latest technology.

\section{Acknowledgment}

The study of green customer behavior is an international collaboration between Bina Nusantara University (Indonesia) and Universiti Teknikal Malaysia Melaka (Malaysia).

\section{References}

[1] D. P. Alamsyah, N. A. Othman, and H. A. A. Mohammed, "The awareness of environmentally friendly products: The impact of green advertising and green brand image," Manag. Sci. Lett., 10, 1961-1968, 2020, doi: 10.5267/j.msl.2020.2.017.

[2] T. F. Kao and Y.Z. Du, "A study on the influence of green advertising design and environmental emotion on advertising effect," J. Clean. Prod., 242, 118294, 2020, doi: 10.1016/j.jclepro.2019.118294.

[3] P. Hartmann and V. Apaolaza-Ibáñez, "Green advertising revisited," Int. J Advert., 28(4), 715-739, Jan. 2009, doi: 10.2501/S0265048709200837.

[4] A. M. F. Paço, M. L. B. Raposo, and B. Interior, "Green Consumer Market Segmentation: Empirical Findings From Portugal," Int. J. Consum. Stud., 34(1996), 429-436, 2010, doi: 10.1111/j.1470-6431.2010.00869.x.

[5] M. H. A. Rahim, R. Z. J. A. Zukni, F. Ahmad, and N. Lyndon, "Green advertising and environmentally responsible consumer behavior: The level of awareness and perception of Malaysian youth," Asian Soc. Sci., 8(5), 4654, 2012, doi: 10.5539/ass.v8n5p46.

[6] B. Cynthia and C. B. Hanson, "Environmental Concern, Attitude Toward Green Corporate Practices, and Green Consumer Behavior in The United States and Canada," ASBBS eJournal, 9(1), 62-71, 2013.

[7] P. Hartmann and V. Apaolaza-Ibáñez, "Green advertising revisted: Conditioning virtual nature experiences," Int. J. Advert., 28(4), 37-41, 2009, doi: $10.2501 / \mathrm{S} 0265048709200837$.

[8] F. N. Jamal, N. A. Othman, R. C. Saleh, and S. Chairunnisa, "Green purchase intention: The power of success in green marketing promotion," Manag. Sci. Lett., 11, 1607-1620, 2021, doi: 10.5267/j.msl.2020.12.011.

[9] F. N. Jamal, N. A. Othman, R. C. Saleh, and A. N. Putri, "Hybrid Structural Equation Model and Dynamic Simulation of Eco Label towards Green Marketing," Syst. Rev. Pharm., 11(12), 956-961, 2020.

[10] S. Omar, N. A. Othman, and J. Jabar, "Effect of eco-innovation practices on sustainable business performance," Pertanika J. Sci. Technol., 25(S5), 123 $128,2017$.

[11] K. Chan, A. Ahmed, and S. Tih, "Green Advertising Appeal and Consumer Purchase Intention," J. Pengur., 47, 157-168, 2016.

[12] C. D'Souza and M. Taghian, "Green advertising effects on attitude and choice of advertising themes," Asia Pacific J. Mark. Logist., 17(3), 51-66, 2005, doi: 10.1108/13555850510672386.

[13] B. Wiryomartono, "'Green building' and sustainable development policy in Indonesia since 2004,” Int. J. Sustain. Build. Technol. Urban Dev., 6(2), 8289, 2015, doi: 10.1080/2093761X.2015.1025450.

[14] D. P. Alamsyah, N. A. Othman, M. H. Bakri, A. N. Adjie, K. Salsabila, and D. Syarifuddin, "Confirmatory factor analysis of green advertising and its impact on green awareness," Manag. Sci. Lett., 10(16), 3899-3906, 2020, doi: $10.5267 /$ j.msl.2020.7.021.

[15] Y. Song and Y. Luximon, "Design for sustainability: The effect of lettering case on environmental concern from a green advertising perspective," Sustain., 11(5), 1333, 2019, doi: 10.3390/su11051333.

[16] M. Merad, N. Dechy, and F. Marcel, "A pragmatic way of achieving Highly Sustainable Organisation: Governance and organisational learning in action in the public French sector," Saf. Sci., 69, 18-28, 2014, doi: 10.1016/j.ssci.2014.01.002.

[17] C.-F. Wei, B. C. Y. Lee, T.-C. Kou, and C.-K. Wu, "Green Marketing: The Roles of Appeal Type and Price Level," Adv. Manag. Appl. Econ., 4(5), 6383,2014

[18] Z. R. Anderson, K. Kusters, J. McCarthy, and K. Obidzinski, "Green growth rhetoric versus reality: Insights from Indonesia," Glob. Environ. Chang., 38, 30-40, 2016, doi: 10.1016/j.gloenvcha.2016.02.008.

[19] M. Sihite, "The Competitive Strategy in Green Building for Indonesian Stakeholder's," Int. J. Innov. Manag. Technol., 6(1), 2015, doi: 10.7763/ijimt.2015.v6.565.

[20] D. P. Alamsyah, T. Suhartini, Y. Rahayu, I. Setyawati, and O. I. B. Hariyanto, "Green advertising, green brand image and green awareness for environmental products," IOP Conf. Ser. Mater. Sci. Eng., 434(1), 012160 2018, doi: 10.1088/1757-899X/434/1/011001.

[21] B. Banerjee and K. McKeage, "How green is my value: exploring the relationship between environmentalism and materialism," ACR North Am. Adv., 1994. 
[22] H. C. Huang, T. H. Lin, M. C. Lai, and T. L. Lin, "Environmental consciousness and green customer behavior: An examination of motivation crowding effect," Int. J. Hosp. Manag., 40, 139-149, 2014, doi: 10.1016/j.ijhm.2014.04.006.

[23] D. P. Alamsyah, O. I. B. Hariyanto, and H. Rohaeni, "Customer Green Awareness and Eco-Label for Organic Products," in International Conference on Organizational Innovation (ICOI), 2019, 100), 64-68, doi: 10.2991/icoi-19.2019.12.

[24] D. L. Gadenne, J. Kennedy, and C. McKeiver, "An empirical study of environmental awareness and practices in SMEs," J. Bus. Ethics, 84(1), 4563, 2009, doi: 10.1007/s10551-008-9672-9.

[25] F. Fuerst and C. Shimizu, "Green luxury goods? The economics of eco-labels in the Japanese housing market," J. Jpn. Int. Econ., 39, 108-122, 2016, doi: 10.1016/j.jjie.2016.01.003.

[26] D. P. Alamsyah and D. Syarifuddin, "Store Image: Mediator of Social Responsibility and Customer Perceived Value to Customer Trust for Organic Products," IOP Conf. Ser. Mater. Sci. Eng., 288(1), 012045, 2017, doi: 10.1088/1757-899X/288/1/011001.

[27] Y. S. Chen and C. H. Chang, "Enhance environmental commitments and green intangible assets toward green competitive advantages: An analysis of structural equation modeling (SEM)," Qual. Quant., 47(1), 529-543, 2013, doi: $10.1007 / \mathrm{s} 11135-011-9535-9$.

[28] Y. Chen and C. Chang, "Enhance Green Purchase Intentions. The Roles of Green Perceived Value, Green Perceived Risk, and Green Trust," Manag. Decis., 50(3), 502-520, 2012.

[29] C. Othman and M. S. Rahman, "Investigation of the relationship of brand personality, subjective norm and perceived control on consumers' purchase intention of organic fast food," Mod. Appl. Sci., 8(3), 92-106, 2014, doi: 10.5539/mas.v8n3p92.

[30] W. Y. Wu, H. Shih, and H. Chan, "A Study of Customer Relationship Management Activities and Marketing Tactics for Hypermarkets on Membership Behavior," Bus. Rev. Cambridge, 10(1), 89-96, 2008.

[31] D. Y. Choi and E. R. Gray, "Socially responsible entrepreneurs: What do they do to create and build their companies?," Bus. Horiz., 51(4), 341-352, 2008, doi: 10.1016/j.bushor.2008.02.010.

[32] A. Davies, A. J. Titterington, and C. Cochrane, "Who buys organic food? A profile of the purchasers of organic food in Northern Ireland," Br. Food J., 97(10), 17-23, 1995, doi: 10.1108/00070709510104303.

[33] A.-I. Maniu and M.-M. Zaharie, "Advertising Creativity - The Right Balance between Surprise, Medium and Message Relevance," Procedia Econ. Financ., 15(14), 1165-1172, 2014, doi: 10.1016/s22125671(14)00573-5.

[34] D. Y. Rahmi, Y. Rozalia, D. N. Chan, Q. Anira, and R. P. Lita, "Green Brand Image Relation Model, Green Awareness, Green Advertisement, and Ecological Knowledge as Competitive Advantage in Improving Green Purchase Intention and Green Purchase Behavior on Creative Industry Products," J. Econ. Bus. Account. Ventur., 20(2), 2017, doi: 10.14414/jebav.v20i2.1126.

[35] R. Fernando, "Sustainable globalization and implications for strategic corporate and national sustainability," Corp. Gov., 12(4), 579-589, 2012, doi: $10.1108 / 14720701211267883$.

[36] D. P. Alamsyah, T. Suhartini, Y. Rahayu, I. Setyawati, and O. I. B. Hariyanto, "Green advertising, green brand image and green awareness for environmental products," IOP Conf. Ser. Mater. Sci. Eng., 434(1), 012160, 2018, doi: 10.1088/1757-899X/434/1/011001

[37] D. P. Alamsyah and H. A. A. Mohammed, "Antecedents of Green Awareness for Eco-Friendly Products," ASEAN Mark. J., 10(2), 109-126, 2019.

[38] Y. S. Chen, C. Y. Lin, and C. S. Weng, "The influence of environmental friendliness on green trust: The mediation effects of green satisfaction and green perceived quality," Sustain., 7(8), 10135-10152, 2015, doi: 10.3390/su70810135.

[39] G. M. Zinkhan and L. Carlson, "Green advertising and the reluctant consumer," J. Advert., 24(2), 1-6, 1995, doi: 10.1080/00913367.1995.10673471.

[40] C. D. Hopkins, K. J. Shanahan, and M. A. Raymond, "The moderating role of religiosity on nonprofit advertising," J. Bus. Res., 67(2), 23-31, 2014, doi: 10.1016/j.jbusres.2013.03.008.

[41] M. Rizwan, U. Mahmood, H. Siddiqui, and A. Tahir, "An Empirical Study about Green Purchase Intentions," J. Sociol. Res., 5(1), 290-305, 2014, doi: $10.5296 /$.

[42] C. Chang, "Are guilt appeals a panacea in green advertising ?," Int. J. Advert., 31(4), 741-771, 2012, doi: 10.2501/IJA-31-4-741-771.

[43] S. J. Grove and N. Kangun, "A content analysis of environmental advertising claims: A matrix method approach les carlson," J. Advert., 22(3), 27-39,
1993, doi: 10.1080/00913367.1993.10673409.

[44] N. M. Suki, N. M. Suki, and N. S. Azman, "Impacts of Corporate Social Responsibility on the Links Between Green Marketing Awareness and Consumer Purchase Intentions," Procedia Econ. Financ., 37(16), 262-268, 2016, doi: 10.1016/s2212-5671(16)30123-x.

[45] G. T. Yeo, V. V. Thai, and S. Y. Roh, "An Analysis of Port Service Quality and Customer Satisfaction: The Case of Korean Container Ports," Asian J. Shipp. Logist., 31(4), 437-447, 2015, doi: 10.1016/j.ajsl.2016.01.002.

[46] Y. Suh and M. S. Kim, "Internationally leading SMEs vs. internationalized SMEs: Evidence of success factors from South Korea," Int. Bus. Rev., 23(1), 115-129, 2014, doi: 10.1016/j.ibusrev.2013.03.002.

[47] C. T. Chang, "Are guilt appeals a panacea in green advertising? The right formula of issue proximity and environmental consciousness," Int. J. Advert., 31(4), 741-771, 2012, doi: 10.2501/IJA-31-4-741-771.

[48] S.-I. Wu and Y.-J. Chen, "The Impact of Green Marketing and Perceived Innovation on Purchase Intention for Green Products," Int. J. Mark. Stud., 6(5), 81-101, 2014, doi: 10.5539/ijms.v6n5p81.

[49] M. V. Oet and S. J. Ong, "From organization to activity in the US collateralized interbank market," Res. Int. Bus. Financ., 50, 472-485, 2019 , doi: 10.1016/j.ribaf.2016.01.012. 